University of Massachusetts Amherst

ScholarWorks@UMass Amherst

Chemistry Department Faculty Publication Series

Chemistry

1979

\title{
The Activities of the Education and Training Group of the Analytical Division of the Chemical Society
}

D. Thorburn Burns

Queen's University Belfast

Julian Tyson

University of Massachusetts Amherst

Follow this and additional works at: https://scholarworks.umass.edu/chem_faculty_pubs

Part of the Analytical Chemistry Commons

\section{Recommended Citation}

Burns, D. Thorburn and Tyson, Julian, "The Activities of the Education and Training Group of the Analytical Division of the Chemical Society" (1979). Fresenius Journal of Analytical Chemistry. 1399.

Retrieved from https://scholarworks.umass.edu/chem_faculty_pubs/1399 


\title{
The Activities of the Education and Training Group of the Analytical Division of the Chemical Society*
}

\author{
D. Thorburn -Burns** \\ Department of Chemistry, The Queen's University of Belfast, Belfast BT 9 5AG, Northern Ireland (Chairman 1976-1978) \\ J. F. Tyson \\ Department of Chemistry, University of Technology, Loughborough, Leicestershire LE11 3TU, U.K. (Honorary Secretary from 1978)
}

\section{Aktivitäten des Bildungsausschusses der Fachgruppe Analytische Chemie der Britischen Chemischen Gesell- schaft}

Zusammenfassung. Zweck des Ausschusses ist die Verbesserung der analytischen Ausbildung an Hochschulen, in der Industrie und überall dort, wo analytisch gearbeitet wird. In Form von Vorträgen und Diskussionen werden Unterrichtsmethoden, Beziehungen zwischen Ausbildung und Berufstätigkeit und andere Probleme behandelt. Die Entwicklung aktueller Probleme wird durch Umfragen (Fragebogenaktionen) beobachtet. Durch zweijährliche Preisverleihungen soll das Interesse der Jugend an Analytischer Chemie geweckt werden.

Summary. The aim of the Education and Training Group of the Analytical Division of the Chemical Society is to improve education and training in Analytical Chemistry at all levels: in universities, in industry, and in all establishments where Analytical Chemistry is practised. Teaching methods, the interface between education and employment and other current problems are dealt with in the form of lectures and discussions. The Group also undertakes a continuing series of questionnaires to monitor the development in this field. A biennial prize is sponsored with the intention of stimulating the interest in Analytical Chemistry amongst young people in the U.K.

Key words: Analytische Chemie; Tätigkeit des Bildungsausschusses der brit. Fachgr. Analyt. Chemie

- Presented at Euroanalysis III conference, Dublin, August 2025,1978

* Address for correspondence
The Education and Training Committee of the Society of Analytical Chemistry was formed and held its first meeting in April 1968 [4]. The Education and Training Group of the Society was founded and held its first Committee meeting on September 24th, 1970. The inaugural meeting of the Group was a two day symposium entitled "Analytical Chemistry - Industrial and Academic Training" held on 24th and 25th September 1970 at the University of Technology, Loughborough $[2,9,12,14]$. By the Annual General Meeting of the Group in October 1971, the membership was 93. The Group has existed in its present form, namely a Group of the Analytical Division of the Chemical Society since 1973.

The primary aim of the Group is to improve education and training in Analytical Chemistry. To this end the Group is concerned with education and training in Analytical Chemistry at all levels; in academic institutions, in industry, indeed, in all establishments where Analytical Chemistry is practised. The Group is also concerned with new and changing trends in Analytical Chemistry and the implications of these on education and training policy and practice.

Meetings of the Group, which are held three or four times a year, consider curricula, teaching and training methods, the interface between education and employment etc. The meetings have taken the form of lectures, discussions or demonstrations many of which have resulted in published material e.g. Industrial and Academic Training $[2,9,12,14]$, general versus specialised L.R.I.C. courses [8], Teaching Atomic Spectroscopy [10], Educational Technology in the service of Analytical Chemistry [15], Recent Trends in Analytical Education [1], Training Graduates [13]. The programme is organised by the Group Committee which is representative of industry, academic institutions and government service from all parts of the United Kingdom and Northern Ireland. 
The Group is concerned to make students aware of career prospects in Analytical Chemistry and of the routes available to obtain specialist qualifications in the subject. To this end the Group has collected and made available, in pamphlet form, information on the ways in which qualifications in Analytical Chemistry may be obtained, and the earlier committee published in 1972 a survey under the title of "Education and Training in Analytical Chemistry at Educational Establishments" [3]. The report was based on replies to questionnaires which were sent out to 59 Universities, 30 polytechnics, 120 colleges of technology, 27 colleges of further education, 19 medical schools and 13 miscellaneous establishments. The Committee commenting on the results noted that the biggest problem encountered in the survey resulted from the variety of ways in which Analytical Chemistry may be defined. It was also noted that most Analytical Chemistry teaching is carried out at colleges of Technology and Polytechnics, whereas research in Analytical Chemistry is located in relatively few Universities (17 out of 59). It was felt that as teaching is invariably stimulated by a research environment it must be regretted that there is a physical separation of these two activities. The Report also pointed out that many important aspects of the teaching of Analytical Chemistry remained obscure, such as, the aspects of analysis dealt with, the equipment available, the excercises set, and the extent to which principles and assumptions are dealt with as opposed to the purely manipulative aspects.

A follow-up survey was published in 1977, ęntitled "Education, Training and Research in Analytical Chemistry in Universities and Polytechnics" [5]. To avoid the problem noted in the first Report, Analytical Chemistry was defined as the examination of a material to establish its properties, qualities and the identification and/or determination of the amount of some or all of its constituents. The Group Committee concluded that of undergraduate level, there had been little change since 1970 and that there had been virtually no expansion of or staff movement into or out of chemistry departments during the previous six years. It was also pointed out that the small number of professors of Analytical Chemistry in the U.K. and Northern Ireland, namely 3 , was completely inadequate and that action to produce more chairs of Analytical Chemistry was long overdue.

The third Report of the Group, "Current Viewpoints on Topics in Analytical Chemistry and their Relevance to Undergraduate Training" [6] is now available. Questionnaires were sent to 45 selected Analytical Chemists in industry and public service and participants were asked to indicate which topics they thought were most important to the training of Analytical Chemists at the undergraduate level. The techniques regarded as vitalwere, titrimetry, gravimetry, $\mathrm{UV} /$ visible spectrometry, atomic spectrometry and gas chromatography.

The Group is also concerned with stimulating an awareness of and interest in Analytical Chemistry amongst young people in the U.K. To this end a biennial prize "The Robert Boyle Essay Awards" is organised on behalf of the Analytical Division of the Chemical Society [11]. The first winner, in 1974, was Mr. Ian C. Hunter (then of Aberdeen Grammar School) whose essay "The Social Importance of Analytical Chemistry" was subsequently published [7]. In 1976 the winner was Mr. P. H. R. Harrison (then of Oundle School). The 1978 winner was Miss A. M. Murphy Bury Convent Grammar School).

\section{References}

1. Crosby, N. T.: Proc. Anal. Div. Chem. Soc. 13, 35 (1976)

2. Downie, T. C.: Proc. Soc. Anal. Chem. 7, 218 (1970)

3. Education and Training Comittee; Proc. Soc. Anal. Chem.9, 173 (1972)

4. Education and Training Group; Proc. Soc. Anal. Chem., 9, 26 (1972)

5. Education and Training Group Comittee: Proc. Anal. Div. Chem. Soc. 14, 1 (1977)

6. Education and Training Group Comittee; Proc. Anal. Div Chem. Soc. 16, 107 (1979)

7. Hunter, I. C.: Proc. Anal. Div. Chem. Soc. 12, 123 (1975)

8. Law, H. D. : Proc. Soc. Anal. Chem. 8, 148 (1971)

9. Lewis, D. T.: Proc. Soc. Anal. Chem. 7, 215 (1970)

10. Price, W. J.: Proc. Anal. Div. Chem. Soc. 12, 119 (1975)

11. Proc. Soc. Anal. Chem. 11, 132 (1974)

12. Puls, H. O.: Proc. Soc. Anal. Chem. 8, 35 (1971)

13. Shaw, W. H. C.: Proc. Anal. Div. Chem. Soc., 14, 54 (1977)

14. Williams, W. J.: Proc. Soc. Anal. Chem. 7, 216 (1970)

15. Williams, W. J. : Proc. Anal. Div. Chem. Soc. 12, 255 (1975)

Received December 19, 1978 